(RESEARCH ARTICLE)

\title{
Synergistic antibacterial activity of Murraya koenigii and Cynodon dactylon against pathogenic strains
}

\author{
Patil Rupali Bhushan ${ }^{1,}{ }^{*}$, Chavan Pranita Sandip ${ }^{1}$ and Desai Deepa Mahendra ${ }^{2}$ \\ ${ }^{1}$ Department of Pharmacognosy, N.S.S. College of Pharmacy, Maharashtra State Board of Technical Education, Mumbai, \\ India. \\ 2 Department of Pharmaceutical Chemistry, N.S.S. College of Pharmacy, Maharashtra State Board of Technical Education, \\ Mumbai, India.
}

Publication history: Received on 07 March 2020; revised on 24 March 2020; accepted on 25 March 2020

Article DOI: https://doi.org/10.30574/wjarr.2020.5.3.0063

\begin{abstract}
The present study deals with the synergistic antibacterial activity of Cynodon dactylon and Murraya koenigii. Combined concentration of the drugs extracts was tested against Escherichia coli, Pseudomonas aeruginosa, Staphylococcus aureus and Bacillus subtilis by agar well diffusion technique. The results of antibacterial activity revealed that the aq. extracts of Cynodon dactylon exhibited maximum to moderate inhibitory activity against all test pathogens. Maximum antibacterial activity by aqueous extract of Cynodon dactylon were exhibited against Escherichia coli, Staphylococcus aureus followed by Bacillus subtilis and Pseudomonas aeruginosa whereas aqueous extract of Murraya koenigii showed moderate sensitivity on all pathogens. Combined concentration of both drugs showed good antibacterial activity against all four pathogens.
\end{abstract}

Keywords: Antibacterial activity; Cynodon dactylon; Murraya koenigii; Agar well diffusion technique

\section{Introduction}

Now a days many infectious diseases have been known to be treated with herbal remedies as it has fewer side effects. Therefore, there has been increasing demand for the drugs from natural sources. Murraya koenigii and Cynodon dactylon are used in traditional medicine as a source of many therapeutic agents in the Indian culture and grows well in the tropical countries [11]. Murraya koenigii known a Curry leaves, locally also known as Karipatha, belonging to Rutaceae family are widely used as a medicinal herb and has characteristic aroma [1].

Murraya koenigii is commonly used as spice due to aromatic nature of leaves and traditionally used as antiemetic, antidiarrheal, blood purifier, antifungal, anti-inflammatory, for kidney pain and to prevent vomiting [2,3]. The Leaves are also a source of an essential oil which finds use in soap and cosmetic aromatherapy industry [4]. It is rich source of Carbazole alkaloids, Carbohydrates, Steroids and Flavonoids[5,6]. Cynodon dactylon is known as Durva grass and is a member of the Family Rutaceae. Some of the medicinal uses/actions of Cynodon dactylon are antiemetic, antidiabetic, diuretic, anti-inflammatory, hepatoprotective activity etc [15]. Its chemical constituents are beta Sitosterol, Beta Carotene, Vitamin C, Palmitic acid, triterpenoids, P-coumaric acid, Cyanogenic glucoside etc.

In the present investigation, attempt has been made to investigate combined antibacterial activity of aq. extract of Cynodon dactylon and Murraya koenigii against some pathogens.

\footnotetext{
* Corresponding author: Patil Rupali Bhushan
} 


\section{Material and methods}

\subsection{Collection of plant material}

Disease free Leaves of Murraya koenigii were collected from the local market of Thane district, Maharashtra. The leaves of Cynodon dactylon were collected from the medicinal garden, Thane, Maharashtra. Leaves were washed thoroughly with tap water and then with distilled water in order to remove any dust, dirty particles present on the surface $[7,8]$. Then leaves were air dried in shade for preparation of extracts.

\subsection{Aqueous extract preparation}

The plant material of Murraya koenigii and Cynodon dactylon were shade dried and powdered by a mechanical grinder. The plant materials of Murraya koenigii and Cynodon dactylon about 20 gms each were sequentially extracted with 200 $\mathrm{ml}$ cold water by maceration process for 5 days at room temperature. The extracts obtained were filtered by using Whatman No.1 filter paper. The extracts were boiled to obtain a syrupy solution $[13,16]$.

\subsection{Selection of bacterial strains}

Medicinally important bacterial pathogens used in this study were Staphylococcus aureus, Pseudomonas aeruginosa, Bacillus subtilis and Escherichia coli and were procured from the Microbiology department, Bharti Vidyapeeth Institute of Pharmacy, Navi Mumbai, India.

\subsection{Test Microorganisms}

Bacterial cultures viz., Staphylococcus aureus, Pseudomonas aeruginosa, Bacillus subtilis, Escherichia coli, were maintained on Nutrient Agar (NA) slants at " $4{ }^{\circ} \mathrm{C}$ ". For further study, cultures have been grown in Nutrient agar slants for 24 hours as overnight cultures [14].

\subsection{Preparation of inoculum}

The pure cultures of bacteria were grown on nutrient agar slants and incubated at " $37^{\circ} \mathrm{C}$ " for $24 \mathrm{hrs}$. Nutrient broth and the slants were stored at " $4{ }^{\circ} \mathrm{C}$ " and maintained in active state by regular sub-culturing for further use [12].

\subsection{Standard reference antibiotic}

The reference antibiotic used was Ciprofloxacin.

\subsection{Drugs and chemicals}

Ciprofloxacin, Agar, DMSO (Dimethyl sulfoxide) were used in the experiment.

\subsection{Agar well diffusion method}

The modified agar well diffusion method was employed [9]. The petri plates were washed and placed in a hot air oven for sterilization [10]. The Nutrient Agar was prepared and poured into different petri plates. The plates were made to solidify in a laminar air flow. Initially, the stock cultures of bacteria were revived by inoculating in broth media and grown at " $37^{\circ} \mathrm{C}$ " for $18 \mathrm{hrs}$. The agar plates of the above media were prepared, and wells were made in the plate. The wells were filled with the different concentrations of sample. The control wells were filled with Ciprofloxacin $(0.5 \mathrm{mg} / \mathrm{ml})$. All the plates were incubated at " $37^{\circ} \mathrm{C}$ " for $24 \mathrm{hrs}$. and the diameter of inhibition zones were noted.

\section{Results}

Antibacterial activity results obtained in the present study revealed that aqueous leaf extract of Murraya koenigii and Cynodon dactylon tested individually possess potential antibacterial activity against bacterial species viz., Escherichia coli, Staphylococcus aureus, Pseudomonas aeruginosa, Bacillus subtilis.

The antibacterial efficacy of the extracts of Murraya koenigii and Cynodon dactylon leaves was quantitatively assessed based on Zone of inhibition in Cm by agar well diffusion method.

The antibacterial activity of both the leaf extract was compared with that of Ciprofloxacin standard against the tested microorganism. 
Table 1 Zone of inhibition in centimeter against the pathogens

\begin{tabular}{|c|c|c|c|c|c|c|c|}
\hline \multirow[t]{2}{*}{ Pathogen } & \multirow{2}{*}{$\begin{array}{l}0.5 \mathrm{mg} / \mathrm{ml} \\
\text { STD }\end{array}$} & \multicolumn{2}{|c|}{$40 \mathrm{mg} / \mathrm{ml}$} & \multirow{2}{*}{$\begin{array}{l}0.5 \mathrm{mg} / \mathrm{ml} \\
\text { STD }\end{array}$} & \multirow{2}{*}{$\begin{array}{l}\text { Sample } 1 \\
(1: 2)\end{array}$} & \multirow{2}{*}{$\begin{array}{l}0.5 \mathrm{mg} / \mathrm{ml} \\
\text { STD }\end{array}$} & \multirow{2}{*}{$\begin{array}{l}\text { Sample } 2 \\
(2: 1)\end{array}$} \\
\hline & & C & $\mathbf{M}$ & & & & \\
\hline Escherichia coli & 4 & 2.8 & 1.8 & 3.8 & 2.4 & 3 & 2 \\
\hline Bacillus subtilis & 3 & 1.1 & 1 & 3.4 & 2.7 & 3.8 & 1.8 \\
\hline Staphylococci & 3 & 1.8 & 2.5 & 3.3 & 2.8 & 3.4 & 2.4 \\
\hline $\begin{array}{l}\text { Pseudomonas } \\
\text { aeruginosa }\end{array}$ & 3.8 & 1.4 & - & 3.6 & 2 & 3.6 & 1.8 \\
\hline
\end{tabular}

Note: C- Cynodon dactylon $\mathrm{M}-$ Murraya koenigii Sample $1-1: 2(\mathrm{M}: \mathrm{C})=40 \mathrm{mg} / \mathrm{ml}: 80 \mathrm{mg} / \mathrm{ml}$ Sample $2-2: 1(\mathrm{M}: \mathrm{C})=80 \mathrm{mg} / \mathrm{ml}: 40 \mathrm{mg} / \mathrm{ml}$

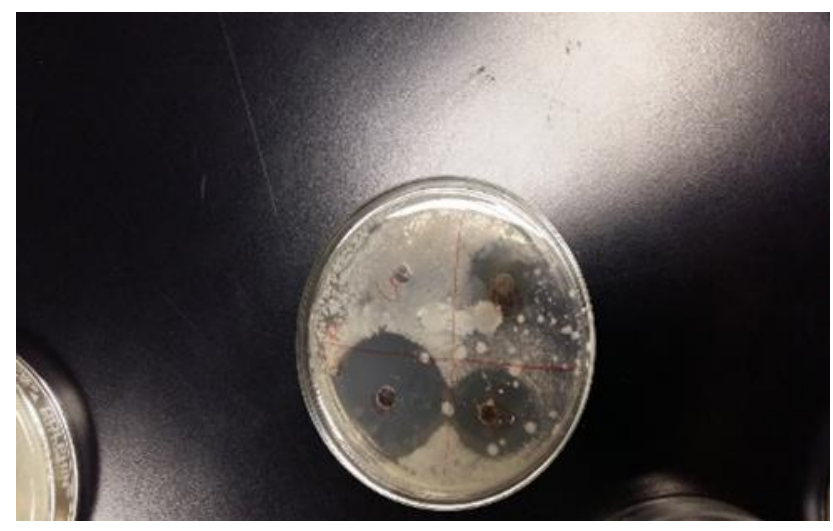

Figure 1 Zone of inhibition of both the drugs against Staphylococci

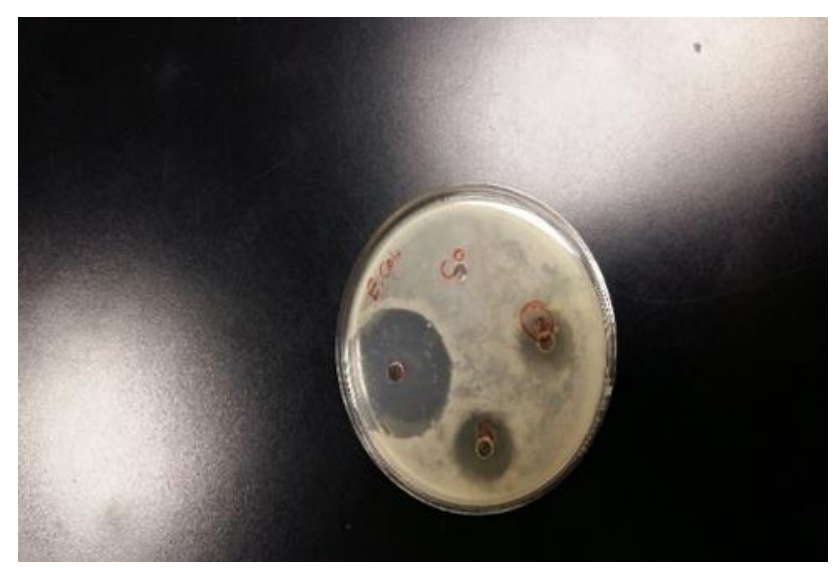

Figure 2 Zone of Inhibition of both drugs against Escherichia coli 


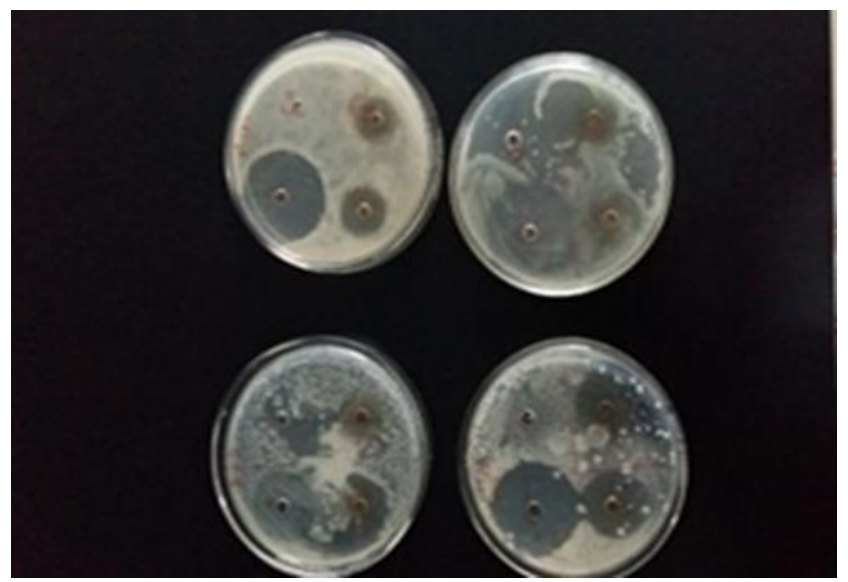

Figure 3 Zone of Inhibition for Sample 1 and sample 2 against Staphylococci and Escherichia coli respectively

\section{Discussion}

In the present investigation, aq. extract of both the drugs tested individually showed moderate zones of inhibition at the conc. of $40 \mathrm{mg} / \mathrm{ml}$ against pathogens. So, combination of both the extracts was used for investigation and it was found to give better results than the individual effect.

Aqueous extract of Cynodon dactylon showed higher sensitivity to all pathogens, except Bacillus subtilis. For aqueous extract of sample 1 (at the ratio specified in the table) maximum zone of inhibition was found to be $2.7 \mathrm{Cm}, 2.8 \mathrm{Cm}, 2.4$ $\mathrm{Cm}$ and $2 \mathrm{Cm}$ at the concentration of $80 \mathrm{mg} / \mathrm{ml}$ of Cynodon dactylon and $40 \mathrm{mg} / \mathrm{ml}$ of Murraya koenigii of plant extracts against Escherichia coli, Staphylococcus aureus, Pseudomonas aeruginosa and Bacillus subtilis. Whereas aq. extract of sample 2 (at the ratio specified in the table) showed moderate sensitivity on all pathogens and zone of inhibition was found to be $2.4 \mathrm{Cm}, 1.8 \mathrm{Cm}, 1.8 \mathrm{Cm}$ and $2 \mathrm{Cm}$ at the concentration of $80 \mathrm{mg} / \mathrm{ml}$ of Murraya koenigii and $40 \mathrm{mg} / \mathrm{ml}$ of Cynodon dactylon of plant extract against Escherichia coli, Staphylococcus aureus, Pseudomonas aeruginosa and Bacillus subtilis respectively.

The present study indicated that when the two drugs were tested at a dose of $40 \mathrm{mg} / \mathrm{ml}$ and $80 \mathrm{mg} / \mathrm{ml}$ in the form of combined extract, the synergistic antibacterial effect is observed. Further, when these two combinations were tried against different bacteria, sample 1 shows reasonably good activity compared to sample 2 .

\section{Compliance with ethical standards}

\section{Acknowledgments}

Nagrik Shikshan Santha's College of Pharmacy, Tardeo, Mumbai for providing facilities to carry out the experimental work.

\section{Disclosure of conflict of interest}

There are no conflicts of interest.

\section{References}

[1] Kumar VS, Sharma A, Tiwari R and Kumar S. (1999). Murraya koenigii (curry leaf): a review. J Med Arom Plant Sci, 21(4), 1139-1141.

[2] Satyavedu GV, Gupta AK and Tendon N. (1987). Medicinal Plants of India, Vol-2, Indian council of medical research, New Delhi India, 289-299.

[3] Khuntia TK, Panda DS. (2011) Evaluation of antibacterial, antifungal and anthelmintic activity of Murraya koenigii Spreng. Pharma Sci Monit , 2(2):105-110.

[4] Rao BRR, Rajput DK and Mallavarapu GR. (2011). Chemical diversity in curry leaf (Murraya koenigii) essential oils. Food Chem, 126(3), 989-994. 
[5] Kartika KR and Basu BD. (1999). Indian Medicinal Plants, Vol III, Second Edn. International Book Distributors, Dehradun, 472-475.

[6] Kumar MM, Vilas SR, Mahesh G, Narendra P and Kailash P. (2010). Antifungal potential of leaf Extracts of Murraya koenigii. IJRAP. 1, 549-552.

[7] Mohan MCH, Rao SM and Kumari P. (2009). Antimicrobial Activity of Selected Indian Medicinal Plants. Journal of Microbiology Biotechnology Environment Science, 11, 355-360.

[8] Maheswari NU, and Cholarani N. (2013). Pharmacognostic effect of leaves extract of Murraya koenigii Linn. Journal of Chemical and Pharmaceutical Research, 5(4), 120-123.

[9] Perez C, Pauli M and Bazevque P. (1990). An antibiotic assay by the agar well diffusion method. Acta Biologiae et Medicine Experimentalis, 15, 113-115.

[10] Shah KJ, Juvekar AR. (2006). Positive inotropic effect of Murraya koenigii (Linn.) Spreng extract on an isolated perfused frog heart. Indian Journal of Experimental Biology, 44, 481- 484.

[11] Kartikey Pandey, CS Singh, Raj Prasad, AK Singh and MK Mishra. (2016). Studies of antimicrobial activity using leaf extract of Cynodon dactylon, Scholar Research library, Der Pharmacia Lettre, 8(3), 325- 330.

[12] Prince Ekisha Gideon Raman Sugumar, and Darling Chellathai David. (2016), An in vitro study of antibacterial and antifungal activity of Cynodon dactylon.

[13] Vipin Kumar G and Sarvesh Kumar Paliwal. (2011). Anti-inflammatory activity of aqueous extract of Cynodon dactylon, 370-375.

[14] Shafaque Rahman. (2014). Cynodon dactylon: Antimicrobial potential of crude extract as valuable medicinal plant, Department of Mathematics and Natural Sciences, BRAC University.

[15] Nindad Shendy and Shailendra S Gurav. (2014). Cynodon dactylon: a systemic Review of Pharmacognosy Phytochemistry and Pharmacology, Int.JPharm Sci, 6(8), 07-12.

[16] Suresh K, Deepa P, Harisaranraj R and Vaira Chaudhari. (2008). Antimicrobial and phytochemical Investigation of the leaves of Carica Papaya L., Cynodon dactylon, Euphoria hirta L, Melia azedarach L and Psidium guajava L, Ethnobotanical leaflets, 12(11), 84-91.

\section{How to cite this article}

Patil RB, Chavan PS and Desai DM. (2020). Synergistic antibacterial activity of Murraya koenigii and Cynodon dactylon against pathogenic strains. World Journal of Advanced Research and Reviews, 5(3), 124-128. 